$\mathrm{RC}$ 造超高層建物の長期地震観 測結果に基づく動特性評価

\title{
DYNAMIC PROPERTIES FOR THE SUPER-HIGH-RISE RC STRUCTURE BUILDINGS BASED ON LONG TERM EARTHQUAKE RECORDS
}

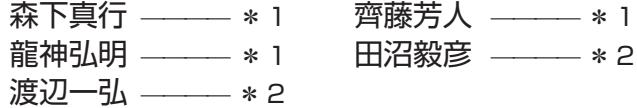

キーワード :

地震観測, RC 造超高層建物, 東北地方太平洋沖地震, 振動特性

Keywords:

Earthquake observation, Super-high-rise RC structure building, 2011 off the Pacific coast of Tohoku Earthquake, Dynamic characteristics

\author{
Tadayuki MORISHITA $-* 1$ \\ Hiroaki RYUJIN — $* 1$ \\ Kazuhiro WATANABE $-* 2$
}

Strong motion records including the 2011 off the Pacific coast of Tohoku Earthquake were obtained at the super-high-rise reinforcedconcrete structure buildings in the Tokyo metropolitan area. Through the estimation of the frequency- relative displacement relation, amplitude dependence and the variation of the natural frequency caused by the inexperienced response relative displacement was confirmed.
1. はじめに

2011 年東北地方太平洋沖地震では, 宮城県で最大震度 7 を観測す るとともに東北地方を中心に広い範囲で震度 6 弱〜 1 の地震動が観 測され，首都圈でも長周期成分が卓越し比較的長い継続時間を有す る摇れを経験している。著者らは，建物動特性の把握ならびに設計 モデルの検証を目的として，首都圈に位置する $\mathrm{RC}$ 造超高層建物 2 棟において竣工時より 15 年以上にわたり地震観測を実施している。 これら 2 棟の建物は建設年が比較的近く, 平面規模ならびに建物高 さともに概ね同程度であり，東北地方太平洋沖地震時に観測開始以 降で最大の摇れを記録するなど類似点が多い。このような同規模建 物において, 竣工後以降の地震観測記録をもとに建物の動特性の比 較的長期間での変動特性ならびに比較的大きな応答経験時の建物の 動特性を分析しその傾向を把握しておくことは，建物の構造健全性 を評価する上での基礎データとして有効であると思われる。

本報では，RC 造超高層建物 2 棟について，比較的長期にわたり得 られた地震観測記録をもとに，建物動特性（固有振動数ならびに減 衰定数）の長期（竣工時以降）および短期（単一地震内）での時間 変動の評価を試みた結果について報告する。

\section{2. 対象建物と地震観測の概要}

2 棟の $\mathrm{RC}$ 造超高層建物および地震観測の概要を図 1 に示す。建物 RA は千葉県に建つ 1992 年竣工の地上 24 階建 (軒高約 70m)の建物, 建物 RB は埼玉県に建つ 1995 年竣工の地上 25 階建（軒高約 $75 \mathrm{~m}$ ）の 建物であり，両建物とも場所打 RC 杭で支持された鉄筋コンクリート 造の純ラーメン構造である。設計周期（基礎固定）は，建物 RA の短 辺方向 1 次が 1.3 秒，短辺方向 2 次が 0.44 秒，建物 RB の短辺方向 1 次が 1.3 秒，短辺方向 2 次が 0.45 秒である。地震観測は 1 階およ び屋上階の 2 点にて実施されており，0.01秒刻み（100Hz サンプリ ング）で加速度応答を収録している。なお，観測は上下動を含む 3
○：屋上階地震計設置位置 口：1階地震計設置位置

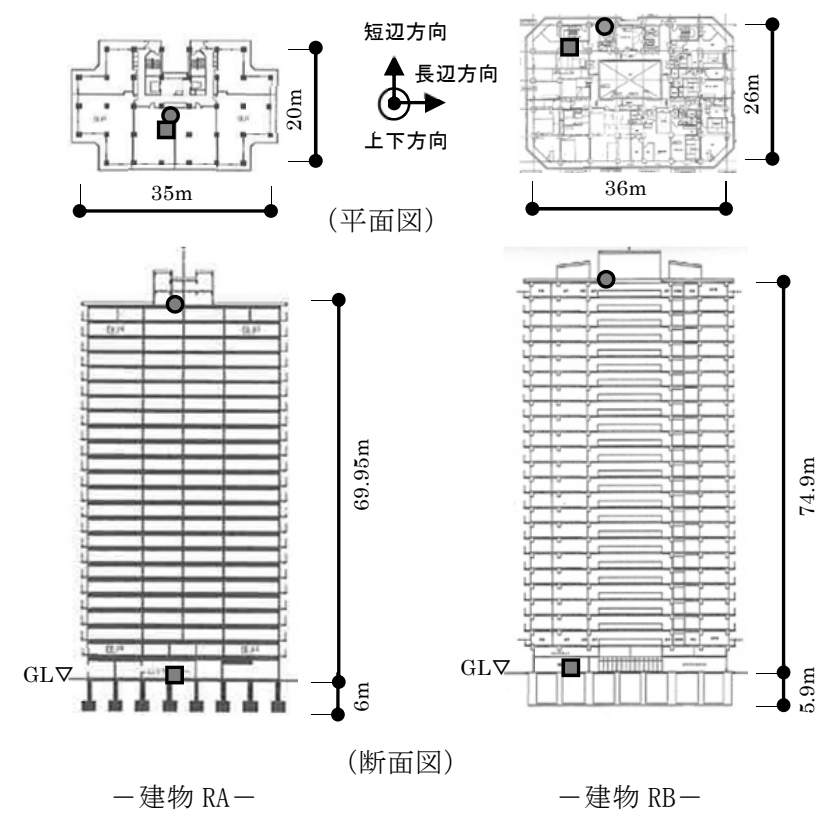

図 1 建物および地震観測の概要

表 1 東北地方太平洋沖地震での観測結果

\begin{tabular}{|c|c|c|c|c|c|}
\hline \multirow{2}{*}{ 建物名 } & \multirow{2}{*}{ 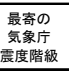 } & \multirow{2}{*}{ 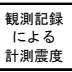 } & \multirow{2}{*}{ 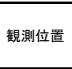 } & \multicolumn{2}{|c|}{ 最大加速度 $\left(\mathrm{cm} / \mathrm{s}^{2}\right)$} \\
\hline & & & & 短讱方向 & 長边方向 \\
\hline \multirow{2}{*}{ RA } & \multirow{2}{*}{5 強 } & \multirow{2}{*}{ 4. 9} & 屋上階 & 392 & 463 \\
\hline & & & 1階 & 139 & 132 \\
\hline \multirow{2}{*}{ RB } & \multirow{2}{*}{5 弱 } & \multirow{2}{*}{ 4. 4} & 屋上階 & 245 & 353 \\
\hline & & & 1階 & 73 & 73 \\
\hline
\end{tabular}

方向の振動を対象に実施されているが，本報では水平 2 方向の振動 のみを検討対象とした。 


\section{3. 東北地方太平洋沖地震での観測結果}

表 1 に東北地方太平洋沖地震（以下， 3.11 地震と呼ぶ）での観測 結果を, 図 2 に東北地方太平洋沖地震時に各建物で観測された応答 波形を, 図 3 に観測波形の周波数分析結果を示す。両建物とも東北 地方太平洋沖地震時に過去最大の加速度を記録している。建物 RA 最寄の気象庁震度階級は 5 強, 当該建物 1 階での観測記録より求め た計測震度は 4.9, 屋上階での最大加速度值は建物長辺方向の 463 $\mathrm{cm} / \mathrm{sec}^{2}$ であり, 同方向での 1 階では $132 \mathrm{~cm} / \mathrm{sec}^{2}$ を観測している。 建物 RB では最寄の気象庁震度階級は 5 弱, 1 階での観測記録より求 めた計測震度は 4. 4, 屋上階での最大加速度値は建物長辺方向の 353 $\mathrm{cm} / \mathrm{sec}^{2}$ であり, 同方向での 1 階では $73 \mathrm{~cm} / \mathrm{sec}^{2}$ を観測している。 周波数分析結果より, 両建物とも各方向で 2 次モードまでの振動成 分が卓越していることが確認できる。図 4 に建物 RA 最上階での長辺 方向の 2 次までのモード抽出波形を参考として示寸。1 次モードの みを抽出した波形の最大值は $253 \mathrm{~cm} / \mathrm{sec}^{2}$ であり, 屋上階での観測 波形最大值 $\left(463 \mathrm{~cm} / \mathrm{sec}^{2}\right)$ の約 $55 \%$ に留まっている。2 次モードま で抽出した波形の最大值は $350 \mathrm{~cm} / \mathrm{sec}^{2}$ であり観測波形最大值の約 $75 \%$ に相当する。波形の全体的な傾向について比較を行う場合でも， 1 次モードのみを抽出した波形では, 最大值での比較同様に観測波 形よりも全体的に小さくなることが確認できる。しかしながら，2 次モードまで抽出した波形と観測波形とを比較すると, 波形の全体 的な傾向は概㸚対応していることが確認できる。従って, 3.11 地震 時の応答波形について全体的な傾向を把握したい場合には, 少なく とも 2 次のモードまで評価する必要があると考えられる。

\section{4. 動特性推定手法}

本報では，建物動特性の時間変動を推定する目的で，代表的なパ ラメータ同定手法である ARX モデルを用いた同定手法を採用する。 システムの方程式は式〔1〕 1)の通りとなる。

$A(q) y(k)=B(q) u(k)+w(k)$

ここで, $u(k)$ は入力, $y(k)$ は出力, $w(k)$ は白色雑音を示す。 $A(q)$ と $B(q)$ は式 [2]で定義されるシフトオペレータ $q$ の多項式とする。

$$
\begin{aligned}
& A(q)=1+a_{1} \cdot q^{-1}+\cdots+a_{n_{a}} \cdot q^{-n_{a}} \\
& B(q)=b_{1} \cdot q^{-1}+\cdots+b_{n_{b}} \cdot q^{-n_{b}} \\
& \text { ここで, シフトオペレータ } q \text { は } q^{-1} x(k)=x(k-1) \text { と定義される関 }
\end{aligned}
$$
係, $a_{1} \sim a_{n_{a}}$ は出力に掛かるモデル係数, $n_{a}$ は出力のモデル次数, $b_{1} \sim b_{n_{b}}$ は入力に掛かるモデル係数, $n_{b}$ は入力のモデル次数であ る。ある同定区間幅での観測記録 $u(k)$ と $y(k)$, 事前に設定したモ デル次数 $n_{a}$ と $n_{b}$ を式〔1〕に代入し最小二乗法を適用してモデル係 数を推定する。得られた $A(q)$ より $A(q)=0$ となる極を算出し, 式 〔3〕 2)より $j$ 次の固有振動数 $\left(f_{j}\right)$ および減衰定数 $\left(h_{j}\right)$ を算出する。

$$
f_{j}=\frac{\left|\log _{z} p_{j}\right|}{2 \pi \Delta t} \quad, \quad h_{j}=\frac{-\log \left|z p_{j}\right|}{2 \pi f_{j} \Delta t}
$$

ここで, ${ }_{z} p_{j}$ は $z$ 変換領域における $j$ 次モードの極, $\Delta t$ はサン プリング周期を示す。

ここでは, 入力 $u(k)$ に 1 階, 出力 $y(k)$ に屋上階の観測記録を適用 した 1 入力 1 出力モデルとして同定を行った。推定は 3.11 地震での
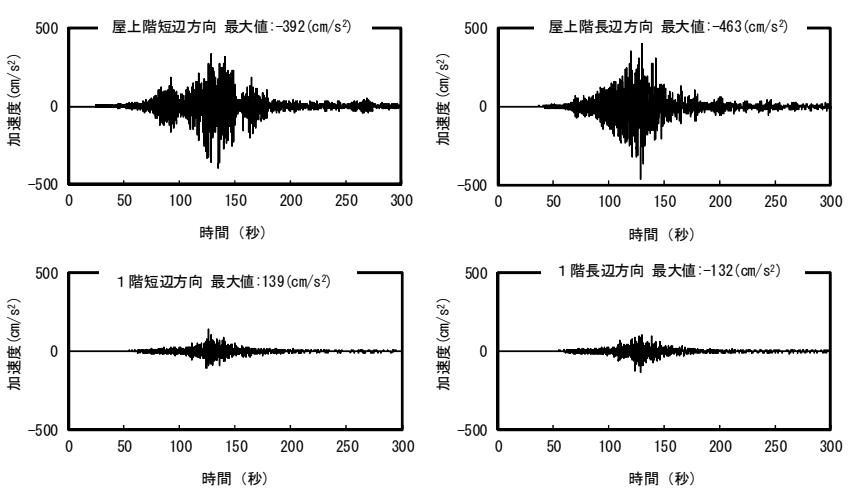

(a) 建物 R A
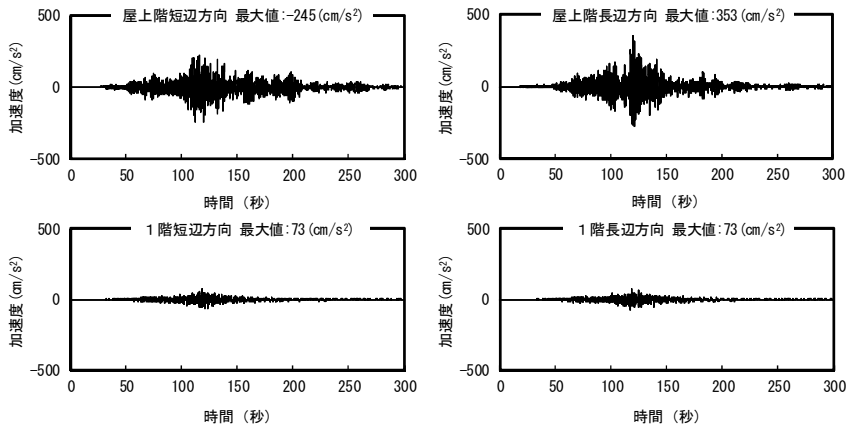

(b) 建物 R B

図 2 東北地方太平洋沖地震での観測波形
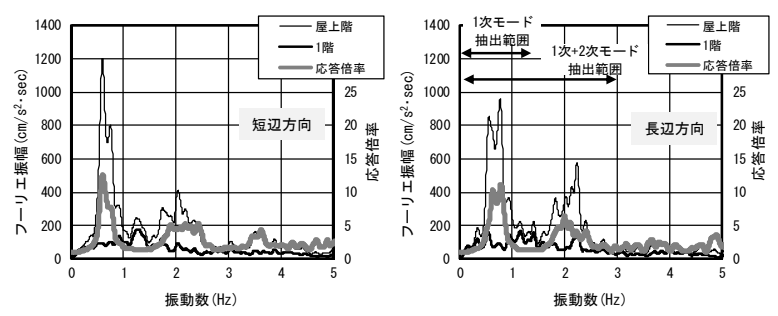

( a ) 建物 R A
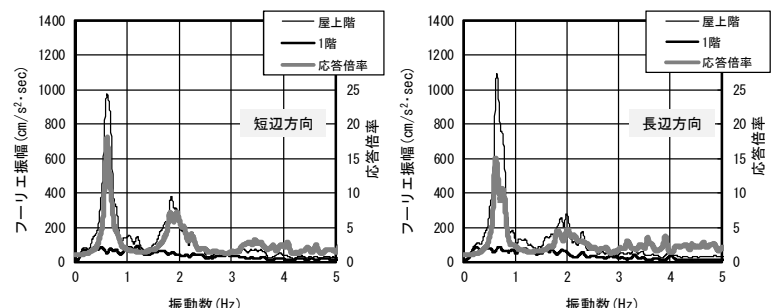

( b ) 建物 R B

図 3 東北地方太平洋沖地震での観測波形の周波数分析結果

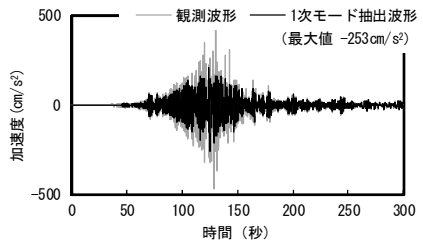

(a) 1 次モードのみ抽出波形

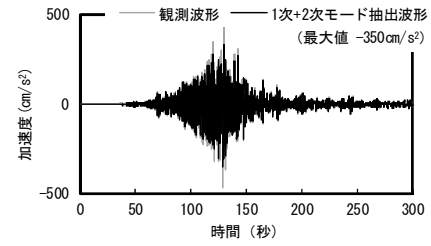

(b) 1 次 +2 次モード抽出波形 図 4 建物 RA 屋上階での長辺方向各次モード抽出波形 
観測波形に関する分析結果を参考に, 2 次モードまでの固有振動数 ならびに減衰定数とした。

本推定手法は線形回帰モデルであるため, 各推定結果は同定区間 幅での等価な值を示す。しかしながら, 建物の動特性は応答振幅に 依存することが知られている ${ }^{3)}$ 。したがって, 同定区間幅を短く設 定するほど建物動特性の時間変動をより厳密に推定可能となる。し かし, 推定結果の安定化の観点からは同定区間幅は可能な限り長く 設定すべきであり, 推定結果の厳密性と安定化はトレードオフの関 係にある。そこで, 本報では同定区間幅として, 各地震の全継続時 間幅に対して別途適用した周波数分析より求めた 1 次の固有周期の 10 倍 ${ }^{4)}$ を採用した。また, 推定精度はモデル次数の設定内容に影響

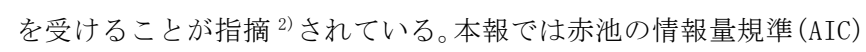
${ }^{5)}$ をデル次数決定時の評価関数として用い, 検討対象地震のうち 各建物で最初に記録された地震記録の全幅に対する評価関数が一定 值に収束した時点でのモデル次数を, 当該建物における全地震共通 のモデル次数として採用することとした。なお, 本建物で評価関数 を検討した結果, モデル次数の増加とともに概ね一定值に収束寸る 傾向を示すことが確認された。よって, モデル次数が $n_{a}=n_{b}=20$ 設 定時の評価関数を基準として, その差が 1 割以内に収束する際のモ デル次数を採用することとし, 同一建物においても方向別に最適な モデル次数を選定した。本報で採用したモデル次数を表 2 に示す。

検討は, まず各建物での初期観測記録より求めた 2 次と 3 次の固 有振動数の中間值（本報では $4 \mathrm{~Hz}$ に設定）を遮断振動数とするロー パスフィルターおよび $0.2 \mathrm{~Hz}$ のハイパスフィルター処理を施した後, $25 \mathrm{~Hz}$ にリサンプリングしたデータを推定対象データとした。次いで, 対象とした地震すべてに対して各データの先頭 5 秒経過時点を同定 の 1 区間目開始時刻に設定し 1 同定区間幅分移動させながら順次同 定を実施した。なお, 検討対象地震は建物竣工後に観測された地震 記録のうち 1 階水平方向で $5 \mathrm{~cm} / \mathrm{sec}^{2}$ 以上の加速度を観測されたも のに限定することで, 建物 RA の検討対象数は 104 地震, 同じく建物 RB は 72 地震とした。

\section{5. 動特性推定結果}

\section{1 応答振幅依存性評価結果}

図 5 および図 6 に建物 RA および建物 RB での固有振動数および減 衰定数の最大相対変位に関寸る応答振幅依存性を, 3.11 地震前, 3.11 地震中, 3.11 地震後に区分けして示す。ここで, 相対変位は同 定区間幅での 1 階に対する最上階の変位波形の差とし, 変位波形は 同定対象とした加速度を周波数領域において 2 階積分して算出した。 なお, 3.11 地震時での相対変位の最大は, 建物 RA では短辺方向で 発生しており最大相対変位 $14.8 \mathrm{~cm}$, 建物 RB では長辺方向で発生し ており最大相対変位 $11.6 \mathrm{~cm}$ であった。最大相対変位と軒高をもとに 算定した建物高さ方向での平均的な層間変形角は建物 RA で $1 / 472$ rad. 程度, 建物 RB で 1/646 rad. 程度となる。また, 3.11 地震後に 建物の目視確認が実施されており, 両建物とも低層階を中心として 非構造部材に軽微な亀裂等の発生していることが確認されている。

建物 RA での固有振動数について, 3.11 地震中は応答振幅の増加 とともに急激に低下寸る特性を示し, 最大振幅後は 3.11 地震前の值 には戻らず固有振動数比で 2 割程度低下した位置に移行する様子が 確認できる。固有振動数の低下度合は異なるが, 同様の傾向は建物
表 2 モデル次数採用結果

\begin{tabular}{|c|c|c|c|c|c|}
\hline \multicolumn{2}{|c|}{} & 建物 $\mathrm{RA}$-短辺方向 & 建物 $\mathrm{RA}$-長辺方向 & 建物 RB-短辺方向 & 建物 $\mathrm{RB}$-長辺方向 \\
\hline \multirow{2}{*}{ モデル次数 } & $n_{a}$ & 13 & 13 & 12 & 12 \\
\cline { 2 - 6 } & $n_{b}$ & 9 & 12 & 9 & 12 \\
\hline
\end{tabular}

$\mathrm{RB}$ でも確認でき, 既往の知見 ${ }^{6)}$ とも整合する結果である。このよう な固有振動数の長周期化の要因として, 非構造部材のなじみ度合の 変化や構造部材での微細なひび割れなどの影響が推測される。

3.11 地震前の 1 次および 2 次の固有振動数の履歴において, 固有 振動数が応答振幅の増大とともに低下寸るいわゆる応答振幅依存の 関係を示寸傾向が確認できる。また, 3.11 地震前の固有振動数の推 定結果は同一振幅においてやや幅を持った分布性状を示し, 3.11 地 震中の固有振動数はその分布範囲の下端に沿って推移する傾向が確 認できる。既往の研究 ${ }^{7)}$ では, 大きな振幅を経験することにより固 有振動数は低下しその後の中小地震でも完全には元の值に戻らない ことが報告されている。3.11 地震前の固有振動数が広がりを持って 推定されている理由の一つとして, 比較的小振幅であったとしても 非構造部材は少なからず影響を受け, その結果, 固有振動数が僅か ではあるが低下する現象の発生している可能性が挙げられる。

3.11 地震後の固有振動数は 3.11 地震後半部での固有振動数の履 歴に沿った範囲で応答振幅依存の関係を示すことが確認でき, その 傾きは 3.11 地震前に比較してやや変化している。この傾向は建物 RB ならびに建物方向によらず概ね同様の傾向を示している。

また, 同図中には竣工時（建物 RAのみ）および 3.11 地震後に屋 上階で実施した常時微動計測より求めた固有振動数を併せて示して いる。竣工時の常時微動計測は長周期振動計により，3.11 地震後は 2012 年 9 月および 2013 年 9 月の 2 回地震観測装置を利用して実施 した結果であり, 竣工時は 1 次モードのみ, 3.11 地震後は 2 次モー ドまでの結果を参考值として示すものである。ここで, 常時微動計 測による固有振動数は屋上単独記録に対する周波数分析結果から求 めた值であり, 動特性推定で採用した伝達系の固有振動数とは異な る性質のものである。しかしながら, 竣工時の常時微動計測結果は 3.11 地震前の比較的小振幅範囲に分布する固有振動数の上端延長 上近傍に, 3.11 地震後の常時微動計測結果は 3.11 地震後の分布範 囲の履歴延長上近傍にそれぞれ位置しており, 常時微動計測時点で の建物の動特性を概ね反映していると考えられる。ここで示した常 時微動計測結果を比較する際は約 20 年間での変化を含むと捉える べきであり, その間に 2 割程度の固有振動数の低下が認められる。

3.11 地震直前での常時微動計測結果が存在しないため, 3.11 地震に よって常時微動計測結果がどの程度変化したかを特定することはで きない。しかしながら, 屋上階での常時微動計測結果に 3.11 地震に よる影響が反映されていることは明確であることから, 常時微動計 測時点での建物の特性が反映された固有振動数の差を建物の健全性 評価の 1 指標として活用できる可能性を示唆する結果である。なお, 一般に常時微動計測結果は非構造部材の特性を含んだものと考えら れており, 常時微動計測結果の比較は単に非構造部材の剛性低下度 合を評価しているに過ぎない可能性がある。この点は, 非構造部材 施工前後での建物の固有振動数を計測し評価するなどして, 非構造 部材の剛性寄与度を別途検討する必要がある。

建物 RA での 1 次の減衰定数に関しては固有振動数ほど明確な傾 向ではないものの, 応答振幅の増大とともに減衰定数が大きくなる 

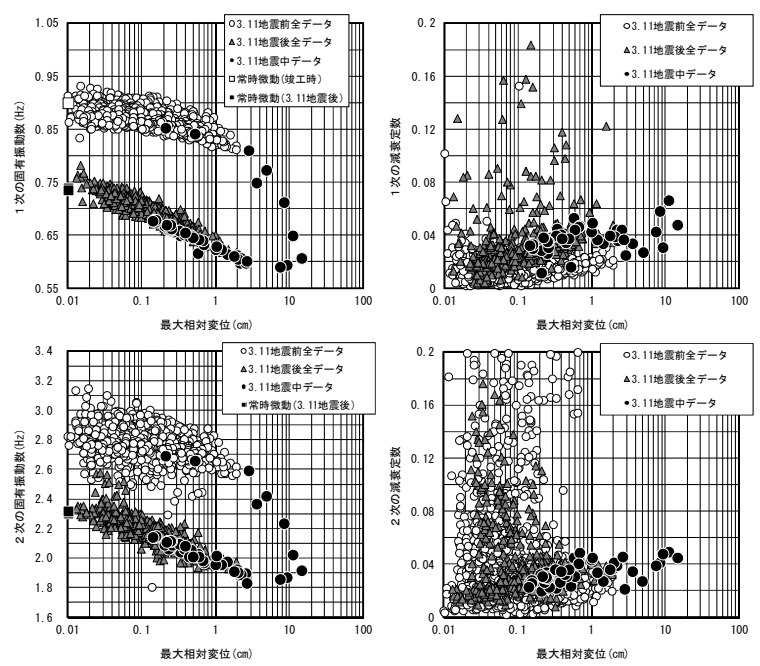

( a ) 建物短辺方向

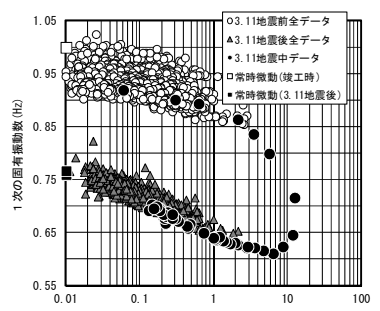

最大相神变位 $(\mathrm{m})$
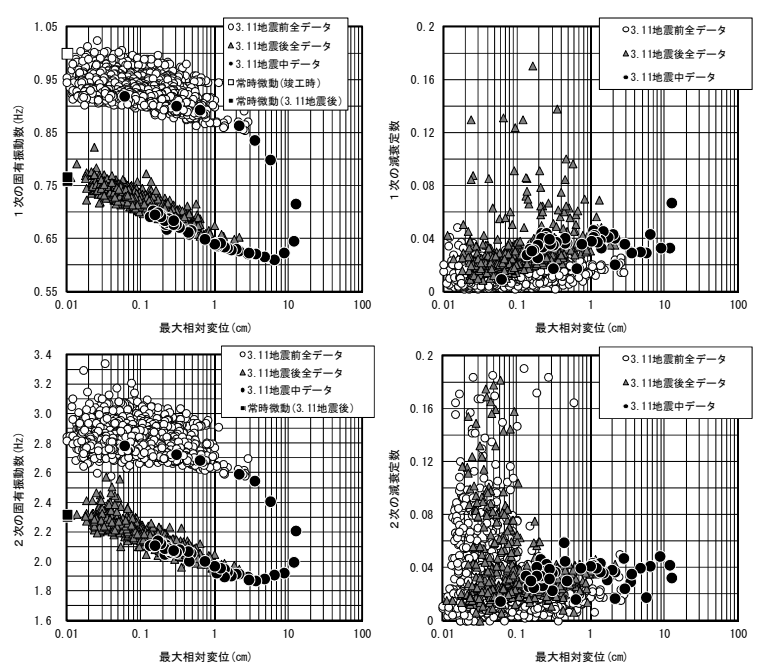

（b）建物長辺方向

図 5 建物 RA での固有振動数および減衰定数の応答振幅依存性

応答振幅依存の関係を示し,その関係は 3.11 地震前後で異なる特性 を示寸傾向が確認できる。すなわち, 3.11 地震前の減衰定数が応答 振幅の増大に応じて概称 1〜3\%の值を示しているのに対して, 比較 的振幅の大きな 3.11 地震中は 3 5\%の值を示す。また, 3.11 地震後 の減衰定数は 3.11 地震中の減衰定数の履歴延長上に移動し, 3.11 地震前に比較して若干ではあるが大きな值を示寸傾向にあることが 確認された。2 次の減衰定数に関しては応答振幅依存性を示寸傾向 は確認できるものの, 1 次の減衰定数に比較して小振幅時のばらつ きが大きく 3.11 地震前後での明確な変化までを確認することは困 難である。これらの傾向は建物方向によらず概数同様である。なお, 本報ではばらつきを含んだ状態での減衰定数に関する検討ではある が, 固有振動数のような相対変位に依存した明確な变動は確認され なかった。減衰定数の推定に関しては, 主要動部を含む比較的応答 振幅の大きな範囲のみを検討区分に選定する，検討区分長をより長 く設定するなどの方策も有効となる可能性があり，同一地震内で推 定された值を安定した範囲のみで平均化する ${ }^{8)}$ な゙゙の方法も提案さ れている。今後は, 推定結果の厳密性確保を念頭に適切な減衰定数 の推定条件についても検討を行う予定である。
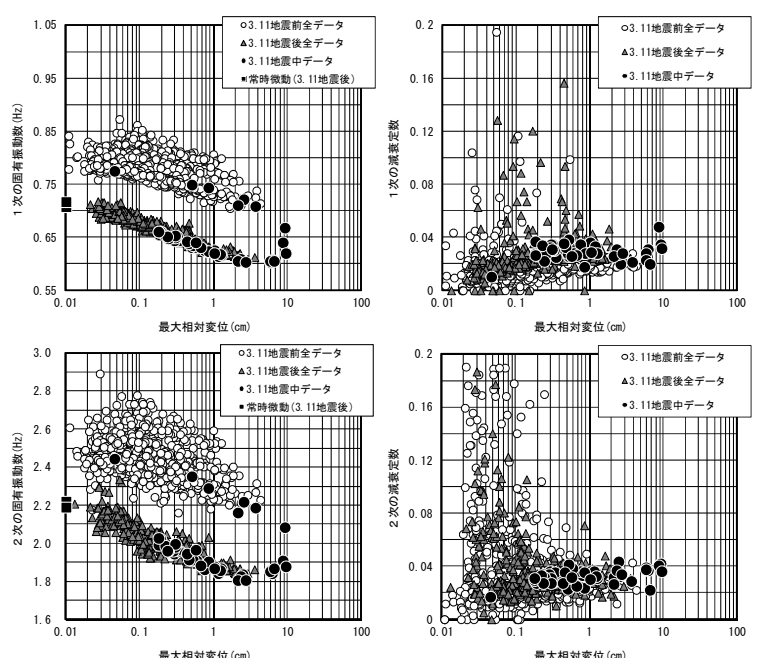

（a）建物短辺方向
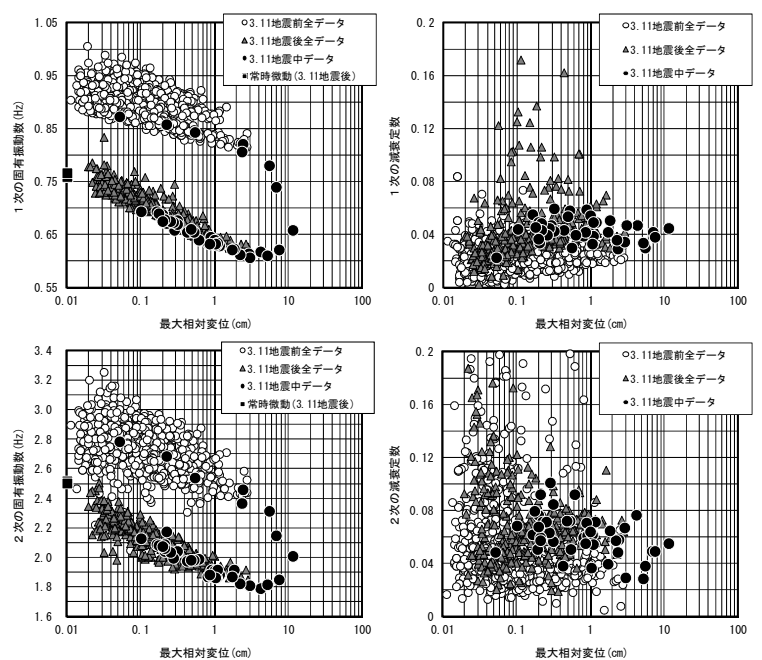

(b) 建物長辺方向

図 6 建物 $\mathrm{RB}$ での固有振動数および減衰定数の応答振幅依存性

\section{2 長期変動評価結果}

前節で, 建物 RA および建物 RB ともに 3.11 地震中に固有振動数は 2 割程度低下し, 3.11 地震後も 3.11 地震前の值に戻っていないこと が確認された。ここでは先に挙げた 3.11 地震前の固有振動数が同一 振幅においてもやや幅を持って分布する要因, 寸なわち比較的小振 幅時であったとしても非構造部材は少なからず影響を受け, 固有振 動数が僅かではあるが低下寸る場合のある可能性について, 長期的 な変動の視点から検討を行う。ここでは, 過去最大の相対変位を経 験した地震記録のみに対して動特性を推定した結果を示し, 過去最 大相対変位との関係について考察する。表 3 に過去最大相対変位を 記録した地震諸元を, 図 7 および図 8 に建物 RA および建物 RB に関 する過去最大相対変位を記録した地震内での動特性変動を示す。な お，参考として過去最大の相対変位を記録しているわけではないが 最新地震での結果も併せて示している。建物 RA 短辺方向での固有振 動数について, RAX(1)地震記録では相対変位も小さく地震中の変動は ほとんど見られない。しかしながら, やや相対変位の大きくなる RAX (2)地震では地震中に固有振動数の低下が認められ, 地震最後部でも RAX(1)地震の最後部での值に完全には戻りきっていない。さらに振幅 
の大きくなるその後の地震（RAX(3), (4)）では, 地震中の固有振動数 の最小值が更新される点, 低下した固有振動数はその後徐々に回復 傾向を示す点, 地震最後部での固有振動数はRAX(2)地震での傾向と 同様に 1 地震前の最後部での值に完全には戻りきっていない点が確 認できる。なお, 長辺方向での結果も含め地震先頭部での固有振動 数は 1 地震前の最後部での值に比較して若干低下している。これは, 推定結果の安定化を図る目的で同定区間幅を 1 次の固有周期の 10 倍に設定したことに起因したものと推測される。すなわち，同定 1 区間目に応答振幅の大きな範囲が含まれ, 純粋な微動レベルでの評 価となっていないためである。観測記録は若干ではあるが地震前の 微動まで遡って計測されるよう設定されているが，本ケースでは同 定区間幅と計測時の遡り時間との関係からこのような現象が発生し たものと推測され，計測条件および分析条件の両面において改善の 余地が残されている。

3. 11 地震では, 最大相対変位の増加に伴い固有振動数が低下し, その後回復傾向を示すこと, 最後部では主要動前の值には完全に戻 りきっていないなどの傾向が明確に捉えられている。3.11 地震では 徐々に最大相対変位が大きくなるため, 最大相対変位の小さな地震 先頭部での固有振動数が推定されており, RAX(4)地震最後部との連続 性が概ね表現されている。RAX(4)地震と 3.11 地震とは 6 年程度離れ ていることから, その間での経年変化や過去最大相対変位を更新し ない地震による影響度合よりも過去最大の相対変位の経験による影 響度合の方が大きいと推察される。なお, 最後部での固有振動数が 1 地震前の最後部での值には完全に戻りきっていない点は 3.11 地震 とそれ以前の地震とで同様の傾向ではあるが, 最大相対変位で 5 倍 以上の開きがあり, 振幅レベルも考慮した要因分析が必要である。

最新地震での固有振動数の回復度合は, ほぼ同程度の最大相対変 位を示す RAX(4)地震時の結果に比較して大きくなっている。このこ とは, 3.11 地震後の応答振幅依存を示寸傾きが 3.11 地震前の傾き に比較してやや変化するとの前節の傾向を裏付ける結果である。こ の傾向は建物 RA 長辺方向や建物 RB においても確認できるが, 現状 では 3.11 地震前後で観測期間や比較データ数に差があるなどの課

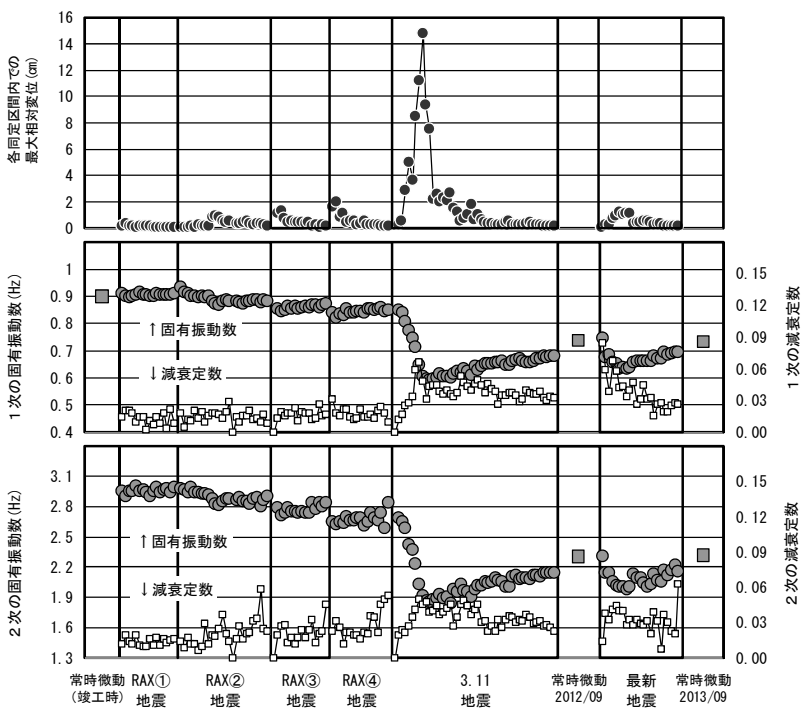

（a）建物短辺方向
題があり, 今後も継続して検討を行う必要がある。

建物 RB での固有振動数についても建物 RA での傾向と概ね整合し た結果であると言える。なお, 建物 RB での結果からは, 地震最後部 での固有振動数と次の地震先頭部での固有振動数とは概ね一致して おり，連続性を示す傾向のあることが確認できる。すなわち，固有 振動数が完全には戻りきらない理由の一つとして, 過去最大相対変 位の経験による可能性が高いとした先の推察を裏付けるものである と考えられる。以上より，3.11 地震前の比較的小振幅時の固有振動 数において, 同一振幅時にやや幅を持った分布性状を示寸現象は地 震前の固有振動数には完全には戻らないことに起因していると考え られ，その発生要因として過去最大相対変位の経験が関係している 可能性の高いことが指摘された。

固有振動数が戻りきらない理由としては見かけ上の剛性低下が想 定され，比較的小振幅時に寄与するものとして例えば非構造部材に よる摩擦やなじみ度合の変化などが考えられる。比較的小さな単一 地震内での固有振動数の変動は 3.11 地震時の変動に比較すると微 小なものであるが, 複数の地震を含めた長期的な変動の中では少な

表 3 過去最大相対変位を記録した地震諸元

\begin{tabular}{|c|c|c|c|c|c|c|c|c|c|c|}
\hline \multirow[b]{2}{*}{ 建物名 } & \multirow[b]{2}{*}{$\begin{array}{l}\text { 地雷発生 } \\
\text { 年月日 時間 }\end{array}$} & \multirow[b]{2}{*}{ 霞央位置 } & \multirow[b]{2}{*}{$\begin{array}{c}\text { 規模 } \\
\text { (M) }\end{array}$} & \multirow[b]{2}{*}{$\begin{array}{l}\text { 霹源 } \\
\text { (km } \\
(\mathrm{km})\end{array}$} & \multirow[b]{2}{*}{ 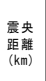 } & \multirow[b]{2}{*}{ 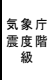 } & \multicolumn{2}{|c|}{ 䧗边方向 } & \multicolumn{2}{|c|}{ 長辺方向 } \\
\hline & & & & & & & 地靁管 & $\begin{array}{c}\text { 建物の最大 } \\
\text { 相対变位 } \\
(\mathrm{cm})\end{array}$ & 地露号 & $\begin{array}{l}\text { 建物の最大 } \\
\text { 相対変位 } \\
\text { (cm) }\end{array}$ \\
\hline \multirow{7}{*}{$\begin{array}{l}\text { 建物 } \\
\text { RA }\end{array}$} & 1993/5/21 11:36 & 茨城県南部 & 5.4 & 61 & 40 & 3 & $\operatorname{RAX}(1)$ & 0.30 & RAY(1) & 0.37 \\
\hline & $1994 / 10 / 42: 56$ & 神奈川県西部 & 4. 4 & 28 & 97 & 3 & $\operatorname{RAX}(2)$ & 0.96 & RAY(2) & 1. 16 \\
\hline & $2000 / 6 / 3 \quad 17: 54$ & 千葉県東方沖 & 6.1 & 48 & 58 & 3 & $\operatorname{RAX}(3)$ & 1. 35 & - & - \\
\hline & $2004 / 10 / 623: 40$ & 茨城県南部 & 5.7 & 66 & 30 & 4 & - & - & RAY(3) & 2. 55 \\
\hline & $2005 / 4 / 117: 22$ & 千蒾県北東部 & 6.1 & 52 & 46 & 3 & $\operatorname{RAX}(4)$ & 1.95 & RAY(4) & 2.87 \\
\hline & $2011 / 3 / 1114: 46$ & 三陸沖 & 9.0 & 24 & 360 & 5 强 & 3.11地震 & 14.8 & 3.11地震 & 12.7 \\
\hline & $2012 / 12 / 7$ 17:18 & 三陸沖 & 7.3 & 49 & 420 & 3 & \begin{tabular}{|l|l} 
最新地震 \\
\end{tabular} & 1. 16 & $\begin{array}{l}\text { 最新地震 } \\
\end{array}$ & 2. 16 \\
\hline \multirow{10}{*}{$\begin{array}{l}\text { 建物 } \\
\text { R B }\end{array}$} & $1995 / 3 / 237: 24$ & 茨城県南部 & 5.1 & 56 & 42 & 3 & $R B X(1)$ & 0.29 & $R B Y(1)$ & 0.25 \\
\hline & $1995 / 7 / 3$ 10:28 & 相模湾 & 5.2 & 122 & 92 & 2 & $\mathrm{RBX}(2)$ & 0.55 & RBY(2) & 0.48 \\
\hline & 1996/9/11 11:37 & 千菜県東方沖 & 6.4 & 52 & 154 & 2 & $R B \times(3)$ & 1. 10 & $\mathrm{RBY}(3)$ & 0.71 \\
\hline & $1996 / 12 / 21 \quad 10: 28$ & 茨城県南部 & 5.6 & 53 & 29 & 3 & $R B \times(4)$ & 1. 28 & $\mathrm{RBY}$ (4) & 1.45 \\
\hline & $2003 / 5 / 26$ 18:24 & 宮城県沖 & 7.1 & 72 & 365 & 3 & $R B X(5)$ & 1.86 & - & - \\
\hline & $2004 / 10 / 23$ 17:56 & 新晹県中越地方 & 6.8 & 13 & 158 & 4 & $R B \times(6)$ & 2. 26 & - & - \\
\hline & $2004 / 10 / 2318: 34$ & 新渴県中越地方 & 6.5 & 14 & 157 & 4 & $R B X(7)$ & 3. 88 & RBY(5) & 2.74 \\
\hline & $2005 / 8 / 16$ 18:34 & 宮城県沖 & 7.2 & 42 & 339 & 3 & $R B X(8)$ & 4. 34 & RBY(6) & 2.81 \\
\hline & $2011 / 3 / 1114: 46$ & 三陸沖 & 9.0 & 24 & 375 & 5 弱 & 3.11地震 & 9.72 & 3.11地震 & 11.6 \\
\hline & $2012 / 12 / 7$ 17:18 & 三陸沖 & 7.3 & 49 & 446 & 3 & \begin{tabular}{|l|l} 
最新地震 \\
\end{tabular} & 2. 35 & 最新地震 & 2. 69 \\
\hline
\end{tabular}

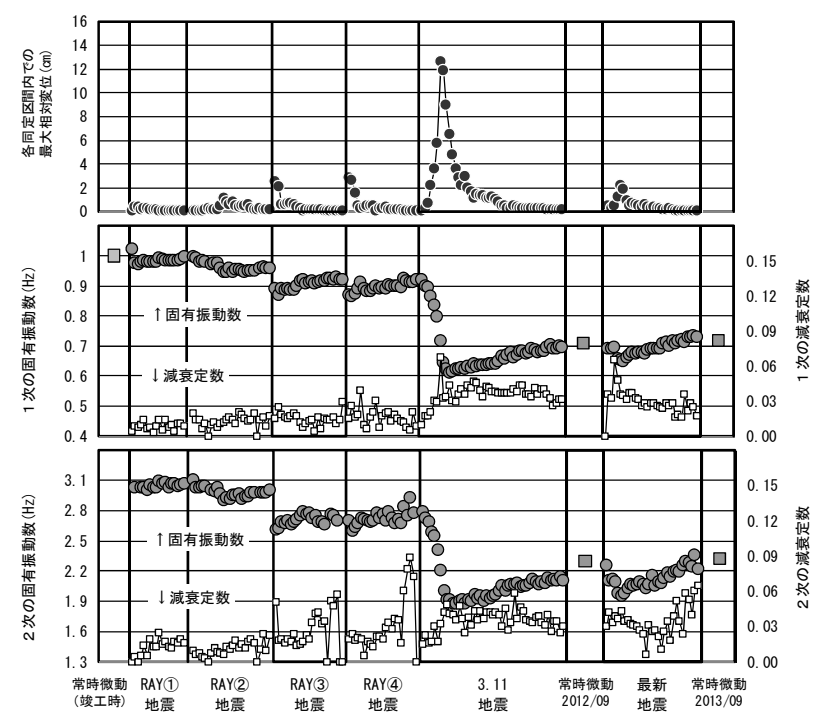

(b) 建物長辺方向

図 7 建物 RA での過去最大相対変位を更新した地震内での動特性変動 


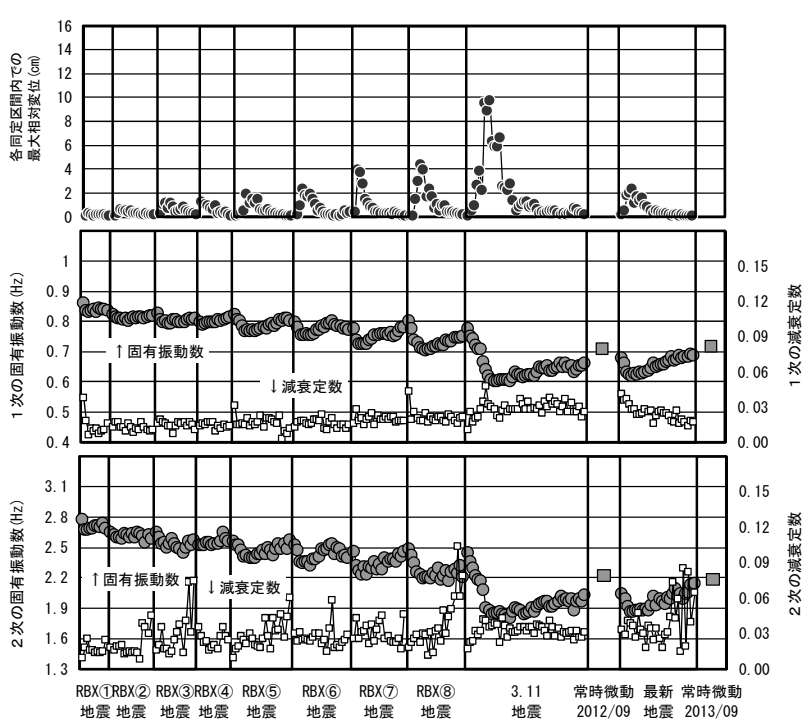

(a ) 建物短辺方向

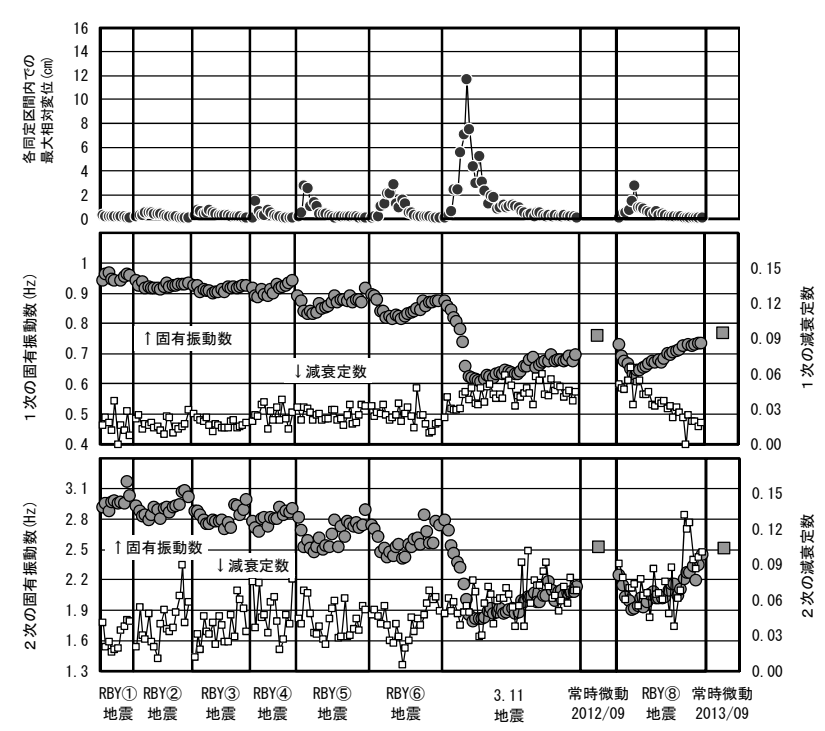

（b）建物長辺方向

図 8 建物 RB での過去最大相対変位を更新した地震内での動特性変動

からず動特性に影響を与えると推察される。このことは, 建物の構 造健全性を評価する場合には, 特定の地震時での動特性評価ととも に長期的な視点での評価も行うことで，より有意義な結論を見いだ せる可能性のあることを示唆する結果である。

減衰定数に関しては, 3.11 地震時において相対的に大きくなる傾 向は確認できるものの, それ以前の地震では固有振動数で指摘され た過去最大相対変位の更新に伴う変化は確認できなかった。

\section{6. まとめ}

首都圈に位置する 2 棟の $\mathrm{RC}$ 造超高層建物での長期にわたる地震観 測記録を用いて，建物動特性（2 次までの固有振動数ならびに減衰 定数）の長期（竣工時以降）および短期（単一地震内）での時間変 動の評価を試みた結果, 以下の結論を得た。

1) 2011 年東北地方太平洋沖地震時に観測された地震応答波形の分 析より, 1 次モードのみから加速度最大值を評価した場合は観測 波形の半分程度に留まることが確認された。長周期地震動の卓越 した首都圈に位置する本建物において，観測波形を評価する上で は，少なくとも 2 次のモードまで評価する必要がある。

2) 3.11 地震時での固有振動数の評価より, 最大相対変位の増加に伴 い固有振動数が低下し，その後回復傾向を示すこと，最後部では 主要動前の值には完全に戻りきっていないなどの点が，2 棟の建 物の共通する特性として確認された。また，3.11 地震後での固有 振動数の応答振幅依存を示寸傾きは 3.11 地震前の傾きとは異な る傾向を示す可能性のあることが指摘された。

3) 3.11 地震前の比較的小振幅時の固有振動数においても, 地震前の 值には戻りきらない場合のあることが確認された。このような現 象が発生する要因の一つとして, 振幅の大きさによらず過去最大 相対変位の経験が関係している可能性の高いことが指摘された。

4) 常時微動計測より求めた固有振動数は, 常時微動前後に発生した 地震時の固有振動数と概ね対応した傾向を示すことが, 3.11 地震 前後ともに確認された。非構造部材の影響度合を別途検討する必 要はあるものの, 常時微動計測時点での建物の特性が反映された
固有振動数の差を建物の構造健全性評価の 1 指標として活用でき る可能性を示唆する結果である。

5) 減衰定数の評価では, 固有振動数のような相対変位に依存した明 確な変動は確認されなかった。本論で推定された減衰定数は, 固 有振動数に比較してばらつきが大きく評価されており，今後は推 定結果の厳密性確保を念頭に適切な減衰定数の推定条件について も検討を行う予定である。

\section{謝辞}

本建物の地震観測は, 独立行政法人都市再生機構との共同研究と して実施しているものであり，東京理科大学 永野教授をはじめUR 超高層集合住宅地震観測合同研究会の関係者各位よりご助言を頂き ました。また, 本研究にあたり, 慶應義塾大学 三田教授主催の「構 造ヘルスモニタリングプロジェクト研究会」で得られた成果を参考 にさせていただきました。ここに記して謝意を表します。

\section{参考文献}

1) 足立修一：「MATLAB による制御のためのシステム同定」, 東京電機大学, 2002. 5 .

2) 斎藤知生 : モード解析型多入力多出力 ARX モデルを用いた高層建物のシス テム同定，建築学会構造系論文集，第 508 号，pp. 47-54，1998.6.

3) 日本建築学会 : 建築物の減衰, pp. 160-177, 2000. 10.

4) 上林宏敏, 大西良広, 林康裕 : 2004 年 9 月紀伊半島南東沖地震の観測記録 に基づく大阪平野の超高層建物の振動特性, 日本建築学会技術報告集, 第 31 号, pp. 679-684, 2009. 10.

5) 赤池弘次他 : 赤池情報量規準, 2008. 6 .

6) 源栄正人, 三辻和弥, 田中匠子, 鹿嶋俊英, 大野晋 : 2011 年東北地方太平 洋沖地震における被害建物の地震前後の振動特性の変化, 日本建築学会大 会学術講演梗概集, B-2, pp. 45-46, 2011.

7) 鹿嶋俊英，北川良和：強震記録に基づく進化戦略手法による建物の振動特 性評価，日本建築学会構造系論文集，第 602 号, pp. 145-152, 2006. 4.

8) 中村充, 勝俣英雄, 福山洋 : 超高層 SRC 建物の地震観測結果に見られる動 特性の振幅依存性, 日本建築学会大会学術講演梗概集, B2, pp. 591-592, 2013 9) 森下真行, 齊藤芳人, 龍神弘明, 渡辺一弘, 田沼毅彦: 長期間の地震観測 記録に基づく $\mathrm{RC}$ 造超高層建物の動特性評価, 日本建築学会大会学術講演梗 概集, B-2, pp. 695-696, 2012.

[2013 年 10 月 16 日原稿受理 2014 年 1 月 24 日採用決定 $]$ 